Max-Planck-Institut für demografische Forschung

Max Planck Institute for Demographic Research

Konrad-Zuse-Strasse 1 - D-18057 Rostock - GERMANY

Tel +49 (0) 3812081 - 0; Fax +49 (0) 3812081 - 202;

http://www.demogr.mpg.de

MPIDR TECHNICAL REPORT 2015-002

MAY 2015

\title{
Demographic Analyses of Church \\ Records: The Case of Infant Mortality in the Hanseatic City of Rostock in the 19th Century
}

Michael Mühlichen (michael.muehlichen@bib.bund.de)

Rembrandt D. Scholz (scholz@demogr.mpg.de)

For additional material see www.demogr.mpg.de/tr/

This technical report has been approved for release by: Vladimir Shkolnikov (shkolnikov@demogr.mpg.de), Head of the Laboratory of Demographic Data.

(C) Copyright is held by the authors.

Technical reports of the Max Planck Institute for Demographic Research receive only limited review. Views or opinions expressed in technical reports are attributable to the authors and do not necessarily reflect those of the Institute. 


\title{
Demographic Analyses of Church Records: \\ The Case of Infant Mortality in the Hanseatic City of Rostock in the 19th Century
}

\author{
Michael Mühlichen and Rembrandt D. Scholz
}

\begin{abstract}
This technical report documents the individual level data preparation of burial and baptismal registers of the church books of St. James in the Hanseatic city of Rostock, Germany, in order to analyze infant mortality in the $19^{\text {th }}$ century. In addition to describing the digitalized registries, data quality, and the construction of variables, this paper presents a new classification of occupations that is also applicable to other historical data sets. The merging of the baptismal and burial data into an event history data set is outlined exemplarily for the time period of 1815 to 1829. The development of infant and perinatal mortality is illustrated by using this data collection.
\end{abstract}

Keywords: infant mortality, historical demography, church registers, social structure

\section{Introduction 1}

Church books provide a useful basis for information on mortality in Germany before the introduction of official statistics. The preparation of these data, however, requires considerable effort, as the handwritten church records must first be transcribed. In this paper, we describe the preparation and editing of the burial and baptismal registers of St. James, the largest church in 19th century Rostock (see Figure 7 in the appendix), as well as the construction of a merged event history data set which contains all live births, stillbirths, and infant deaths registered in St. James between 1815 and 1829. This data set allows for the calculation of cohort-based infant and perinatal mortality rates, as well as models of event history analysis in order to measure the influence of social, demographic, and climatic factors. Furthermore, we present a new classification that can be used for grouping different types of occupations as well as sorting occupations by social class. The edited data are enclosed with this data report in Excel and SPSS format.

\footnotetext{
1 For more background information on the project, see Mühlichen \& Scholz (2015).
} 


\section{Data and Methods}

Data on live births and infant deaths are necessary to calculate infant mortality. The live births are recorded in the baptismal registers, whereas the infant deaths are contained in the burial registers. St. James is the only parish in Rostock which has a digitalized version of its baptismal registries ${ }^{2}$.

The historic city of Rostock consisted of four parishes: St. James, St. Mary, St. Nicolas and St. Peter. The parish of St. James was by far the largest, comprising more than half of the total city population among its members in 1905, which led to a division of the parish and the foundation of the Church of the Holy Ghost in 1908 (Schulz 2008: 24; Szołtysek et al. 2012: 10) ${ }^{3}$. St. James, however, was not only the largest parish, but was also most likely the most heterogeneous concerning the social structure of its members (Mühlichen \& Scholz 2015). Although an analysis of all Rostock parishes would be necessary to gain knowledge on the entirety of Rostock's population, we consider the data of St. James to be very representative and a suitable sample for the entire city.

\subsection{Burial Registers}

The Max Planck Institute for Demographic Research (MPIDR) maintains a scanned catalogue of the burial registers of St. James from 1740 to 1911. From 1740 through 1786 the registry lists only the names of the deceased. Because the age of death was not recorded, this period could not be considered for the analysis of infant mortality. As of 1787, however, the burial register is listed in tabular form and includes the following items 4 : a running number 5 , the date of death, the date of the funeral, the complete decedent's name including all (or most of the) first names, the decedent's age at death, the cause of death, as well as the parents' names and the father's occupation. The decedent's sex is not directly recorded but can be derived from the first name.

Up until and including 1846, if the parents were married, only information on the father was recorded. In the case of illegitimate births - if the mother was not married at the

\footnotetext{
2 The Max Planck Institute for Demographic Research maintains a database of church book scans from all Rostock parishes. Whereas many burial lists have been digitalized as electronic tables in Excel format, only the baptismal registries of St. James have (in parts) been typed as transcriptions.

3 St. James no longer exists. Large parts of the church were destroyed in 1942 during a British bombing raid. The remaining structure was torn down in 1960 (Köppe 2010; Kuzia 2004).

${ }^{4}$ Figure 1 shows a section of the baptismal register from 1815 and a section of the burial register from 1816.

5 This number is not a serial number which is identical for the same person across different registers, as is the case in modern panel data. It is simply a running number starting at 1 in each register for every church year. Thus, it holds no meaning to our analyses.
} 
time of birth - the name and (in very few instances) the occupation of the mother was registered, whereas no information on the father was provided. Thus, the mother's marital status and the status of legitimacy of the birth can be deduced. From 1847 onwards, a column for the mother was introduced, and illegitimate births were marked. Also starting in 1847, the place of birth was documented. Beginning in 1831, the decedent's heirs were also registered, which is, however, irrelevant for infant deaths. Furthermore, if the funeral did not take place at St. James, this place was also recorded. Starting in 1800, stillbirths, which are necessary for the calculation of perinatal mortality rates, were also documented.

\subsection{Baptismal Registers}

The baptismal register is similarly structured and varies over time as well. The earliest period available as scanned documents at the MPIDR dates from 1761 to 1786 and is recorded in a textual form. For the period from 1787 to 1911, the register is listed in tabular form and contains the following items: a running number, the date of birth, the date of baptism, the complete names of the parents and their newborn child, the occupation of the father and (in very few instances) the mother, the name of the pastor conducting the baptism ceremony, as well as the names of the relatives who were present at or absent from the baptism. In some cases, the place of birth is mentioned as well, if different from Rostock. Moreover, in a few instances the parents' or relatives' place of origin is also recorded. In parallel to the burial register, stillbirths are also documented in the baptismal register, but only through the year 1876.

Figure 1 shows a section of the baptismal register from the year 1815 on the left and a section of the burial register from 1816 on the right. In the last row of both lists, we find the same person, a girl named Emma. She was born on 28 January 1815, baptized on 5 February 1815; she died at the age of 11 months on 31 December 1815 and was buried on 5 January 1816. 
Figure 1: Sections from the baptismal and burial registers of St. James parish, Rostock

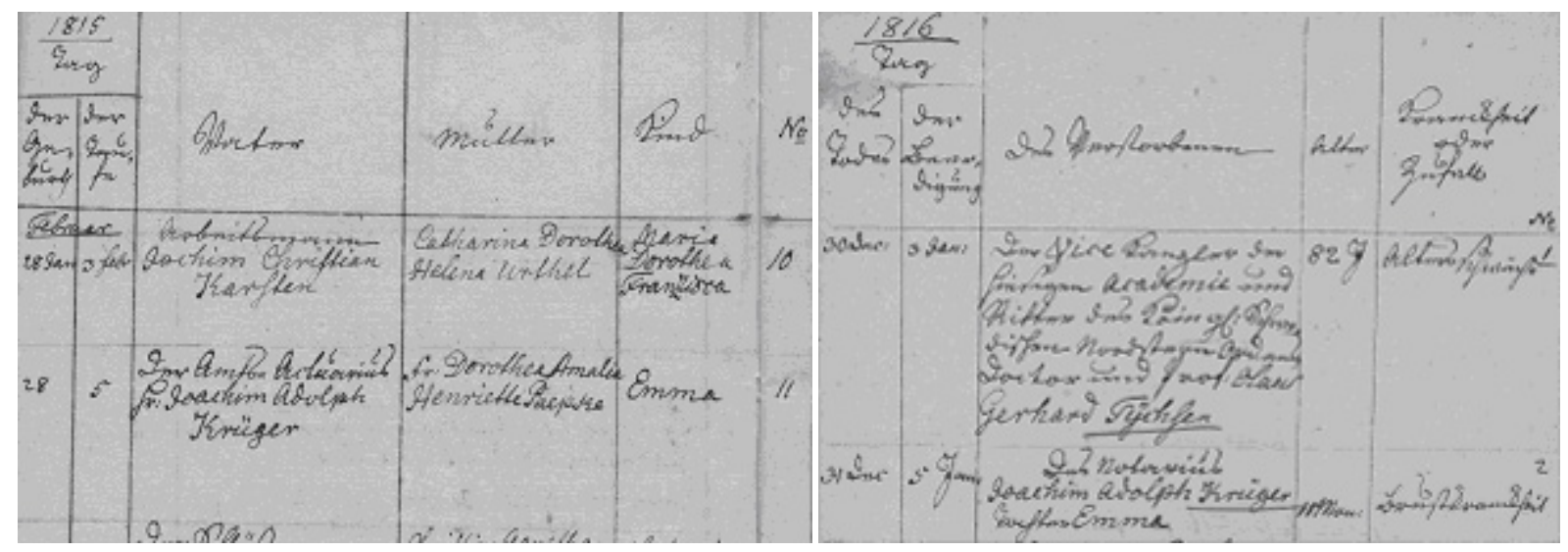

Source: Baptismal register of 1815 and burial register of 1816 of St. James parish, Rostock

\subsection{Matching of the Burial and Baptismal Registers}

All data on stillbirths and live births who died before their first birthday were transferred from the 1787-1910 burial registers of St. James into an Excel spreadsheet. Likewise, all cases from the baptismal registers of St. James were typed into a separate Excel sheet for the periods of 1815-1829, 1863-1879, 1881, 1898-1901, and 1903-1904. In addition, we counted the births according to sex and (from 1847 onwards) place of birth for the gap years, in order to be able to calculate infant mortality rates for the entire $19^{\text {th }}$ century. All burial data and the baptismal data from 1815-1829 were subjected to a comprehensive process of error correction.

The next step was matching the two data sets for the period of 1815-1829. Such a matching process required great effort, as there is no personal identification number as a key variable in historical registries. Therefore, we matched the two data sets by name. The baptismal and burial lists contain the complete names of the infants and their parents, so it is possible to identify individuals who appear in both. However, the order of the first names, as well as the spelling of the first and last names often differed slightly in the two registers. This means that any programming for an automated matching procedure would not have produced fully reliable results. For this reason, we manually attached the infant death data from the burial data set to the baptismal data set after harmonizing the columns. Subsequently, we sorted the data set by last and first names of the infants in order to find identical cases. After transferring the additional information from those rows that contained the burial data into the rows that included the baptismal data, we deleted the attached rows. 
In the end, the merged data set included the following items: name, date of birth, date of baptism, date of death, date of funeral, sex, age at death, cause of death, name and occupation of the father, name and marital status of the mother (and in very few instances her occupation), name of the pastor performing the baptism, as well as other remarks and a list of relatives who were present at the baptism. Before publishing the data set online, however, we deleted all columns containing names for the purpose of anonymization. Further adjustments of the data set for the use of event history analysis are described in the following two sections and in Mühlichen et al. (2015).

After having completed the data preparation, the data set contains 2,794 live births from the period of 1815 to 1829 . The number of infants who died in their first year of life is 351 , or $12.78 \%$, of all births. The number of stillbirths is 124 , or $4.25 \%$.

\subsection{Data Quality}

Immigration and emigration create deviations from the population at risk and, thus, distortions in the data of infant mortality. Immigrated persons are easy to find: They are listed in the burial but not in the baptismal registers. We know the dates of their death and their funeral, but we do not know the exact dates of birth and baptism. It is possible to exclude those cases from the analyses. However, we have no information on emigration; meaning we do not know which of the infants who were born in Rostock moved away and died in another place.

Another problem is the determination of live birth and stillbirth. In the $19^{\text {th }}$ century there was no definition and presumably no consistent distinction between the two terms. In fact, it cannot be ruled out that regional differences in infant mortality in $19^{\text {th }}$ century Germany were partly related to different distinction practices of live birth and stillbirth. Moreover, there was also no uniform German classification of the causes of death. Especially at the beginning of the $19^{\text {th }}$ century, the description of the causes of death was quite undifferentiated and inaccurate. In addition, the diagnosis was not made by a physician, but by the respective pastor. However, the pastors in the region of Mecklenburg-Schwerin, to which Rostock belonged, apparently had sound basic medical knowledge, as can be deduced from the clerical statute books of Mecklenburg-Schwerin (e.g. Gesenius 1839, 1847; Millies 1895, 1896, 1910). Over the course of the $19^{\text {th }}$ century, as medical knowledge grew, the diagnoses improved. 
All in all, the quality of the data is - with regard to the time they date from - quite good because (1) the date of birth is recorded, which is generally not a given in baptismal registers, and (2) because the father's occupation is recorded, which allows for consideration of certain socioeconomic influences.

\subsection{Construction of Variables}

In event history analysis, the dependent variable is the hazard rate, which is defined as the intensity at which events occur over time (see Allison 1984). The time of exposure to the risk of interest and the respective events are used for the calculation of the hazard rate. In our analysis, the risk of interest is the risk of death within the first year of life. Thus, the respective event is the onset of death and the time of exposure is the period from birth to the onset of death or to the time of censoring 6 , respectively. The event variable is coded as a dummy variable, 1 meaning that an event occurred, e.g. the infant died within the first year of life, and 0 meaning that no event occurred, i.e. the newborn survived the first year of life. The analysis time is measured in days from 1 to less than 365 . The time value is set to 99999 when no death occurred within the first year of life.

Explanatory variables in this data set are the sex, the season of birth, the legitimacy of birth, and the father's occupation. Other variables available in the data set are listed in Table 3 (appendix).

The sex is coded as $1=$ male and $2=$ female. In only one case - a stillbirth - the sex cannot be derived from the registers. The season of birth is coded as 1=spring, 2=summer, $3=$ autumn and $4=$ =winter. The seasons are divided by the meteorological classification, i.e. spring lasts from March to May, summer from June to August, autumn from September to November, and winter from December to February. The legitimacy of birth is operationalized as $1=$ legitimate and $2=$ illegitimate. The second category also includes a few cases of married mothers in which the husband is not the father.

\subsection{Classification of Occupations}

The data set originally listed 377 different paternal occupations. First, variant forms of spelling were harmonized, which reduced the number of occupations to 269. These

\footnotetext{
6 There are two cases of right censoring in the data: First, the completion of the first year of life and, second, the migration out of the population at risk to another place. Concerning the latter point, we do not have any information on frequencies and survival probabilities of emigrated infants.
} 
labels are listed in the accessible data set. In the next step, the classification of occupations (OCCHISCO) of the North Atlantic Population Project (NAPP), which is an adaptation from the Historical International Standard Classification of Occupations (HISCO) coding scheme ${ }^{7}$, was applied to the data set, further reducing the number of occupations to 107.

The OCCHISCO does have some disadvantages for the social sciences, such as the great number of occupational groups and the missing orientation by social classes. Therefore, using the works of Brandenburg et al. (1991), Lorenzen-Schmidt (1996), and Brandenburg \& Kroll (1998) for Northern Germany as well as historical lexica ${ }^{8}$, we have created a classification that is more suitable for a Hanseatic city and allows aggregating by both occupational groups and social classes. The financial situation within occupational groups was quite different. Craftsmen, for instance, were a very heterogeneous group, with master and apprentice craftsmen, whereas merchants, brewers, jurists, and professors formed the economic elite in Rostock (Manke 2000: 369-371). In order to consider different socioeconomic statuses within occupational groups, we incorporated additional codes for master (--1) and apprentice (--2) craftsmen. In the groups of shipping and military we used this scheme as well in order to differentiate between statuses.

In the end, our new classification resulted in 65 occupations in the data set, which are assigned to 8 broad occupational groups and one residual category. An aggregation of the occupations by three social classes is described in Mühlichen et al. (2015).

The upper groups generated for the father's occupation are 1=trade, $2=$ craftsmanship, $3=$ =services, 4=administration and higher status occupations, 5=agriculture, 6=food production, $7=$ shipping and military, $8=$ industry and $9=$ unknown or no occupation. The eighth upper group for industrial occupations is useful for later periods but is not relevant for our pre-industrial period of study. An overview of the upper groups, including their various manifestations, is shown in Table 1; a more detailed overview is shown in Table 4 (appendix).

\footnotetext{
7 More information on HISCO and the NAPP adaptation can be found, for instance, in Van Leeuwen et al. (2002), Roberts et al. (2003), Van Leeuwen \& Maas (2011), and North Atlantic Population Project (2013).

8 We used the historical German lexica of Adelung 1793-1801, Pierer 1857-1865, Meyers 1905-1909, and Brockhaus 1911 that are freely accessible through the online library Zeno.org.
} 
Table 1: Frequencies and shares of the father's occupational groups and subgroups in St. James parish, Rostock, from 1815 to 1829

\begin{tabular}{|c|c|c|c|c|c|}
\hline \multicolumn{6}{|c|}{ Occupational group } \\
\hline Code & German job title & English translation & $\mathbf{N}$ & \%OG & \%TOT \\
\hline \multicolumn{6}{|l|}{ Trade } \\
\hline 100 & Händler, sonstige & Tradesman, other & 14 & 4.4 & 0.5 \\
\hline 110 & Kaufmann & Merchant & 110 & 34.7 & 3.8 \\
\hline 120 & Drögköper & Grocer & 36 & 11.4 & 1.2 \\
\hline 130 & Fuhrmann & Carter & 103 & 32.5 & 3.5 \\
\hline \multirow[t]{2}{*}{140} & Gastwirt, Herbergierer & Innkeeper & 54 & 17.0 & 1.9 \\
\hline & Total & & 317 & 100.0 & 10.9 \\
\hline \multicolumn{6}{|c|}{ Craftsmanship } \\
\hline 200 & Handwerker, sonstige & Craftsman, other & 35 & 4.5 & 1.2 \\
\hline 201 & Handwerksmeister, sonstige & Master craftsman, other & 1 & 0.1 & 0.0 \\
\hline 202 & Handwerksgeselle, sonstige & Apprentice craftsman, other & 11 & 1.4 & 0.4 \\
\hline 210 & Bauhandwerker & Construction worker & 64 & 8.3 & 2.2 \\
\hline 211 & Bauhandwerksmeister & Construction master & 6 & 0.8 & 0.2 \\
\hline 212 & Bauhandwerksgeselle & Construction apprentice & 8 & 1.0 & 0.3 \\
\hline 220 & Holzhandwerker & Carpenter & 177 & 22.9 & 6.1 \\
\hline 221 & Holzhandwerksmeister & Master carpenter & 15 & 1.9 & 0.5 \\
\hline 222 & Holzhandwerksgeselle & Apprentice carpenter & 33 & 4.3 & 1.1 \\
\hline 230 & Schiffshandwerker & Ship carpenter & 86 & 11.1 & 3.0 \\
\hline 231 & Schiffshandwerksmeister & Master ship carpenter & 1 & 0.1 & 0.0 \\
\hline 232 & Schiffshandwerksgeselle & Apprentice ship carpenter & 41 & 5.3 & 1.4 \\
\hline 240 & Textilhandwerker & Textile craftsman & 67 & 8.7 & 2.3 \\
\hline 241 & Textilhandwerksmeister & Master textile craftsman & 43 & 5.6 & 1.5 \\
\hline 242 & Textilhandwerksgeselle & Apprentice textile craftsman & 5 & 0.6 & 0.2 \\
\hline 250 & Schuhmacher & Shoemaker & 103 & 13.3 & 3.5 \\
\hline 251 & Schuhmachermeister & Master shoemaker & 10 & 1.3 & 0.3 \\
\hline 252 & Schuhmachergeselle & Apprentice shoemaker & 0 & 0.0 & 0.0 \\
\hline 260 & Metallhandwerker & Metalworker & 43 & 5.6 & 1.5 \\
\hline 261 & Metallhandwerksmeister & Master metalworker & 4 & 0.5 & 0.1 \\
\hline 262 & Metallhandwerksgeselle & Apprentice metalworker & 1 & 0.1 & 0.0 \\
\hline 270 & Maler & Painter & 19 & 2.5 & 0.7 \\
\hline 271 & Malermeister & Master painter & 0 & 0.0 & 0.0 \\
\hline \multirow[t]{2}{*}{272} & Malergeselle & Apprentice painter & 0 & 0.0 & 0.0 \\
\hline & Total & & 773 & 100.0 & 26.5 \\
\hline \multicolumn{6}{|l|}{ Services } \\
\hline 300 & Arbeitsmann & Laborer (not otherwise specified) & 482 & 84.7 & 16.6 \\
\hline 310 & Lohndiener, Tagelöhner & Hired servant, day laborer & 39 & 6.9 & 1.3 \\
\hline 320 & Träger & Porter & 33 & 5.8 & 1.1 \\
\hline \multirow[t]{2}{*}{330} & Musicus, Spielmann & Musician & 15 & 2.6 & 0.5 \\
\hline & Total & & 569 & 100.0 & 19.5 \\
\hline \multicolumn{6}{|c|}{ Administration and higher status occupations } \\
\hline 400 & Sekretär, Schreiber & Clerk, administrative secretary & 13 & 6.2 & 0.4 \\
\hline 401 & Höherer Beamter & High-level official & 62 & 29.5 & 2.1 \\
\hline 402 & Rathaus-/Kirchen-/Gerichtsdiener & Low-level official & 35 & 16.7 & 1.2 \\
\hline 410 & Jurist & Jurist & 55 & 26.2 & 1.9 \\
\hline 420 & Lehrer, Professor & Teacher, professor & 22 & 10.5 & 0.8 \\
\hline 430 & Diakon, Pastor, Kantor & Clergyman & 8 & 3.8 & 0.3 \\
\hline 440 & Mediziner & Physician & 11 & 5.2 & 0.4 \\
\hline \multirow[t]{2}{*}{450} & Adel, Gutsbesitzer & Nobleman, landowner & 4 & 1.9 & 0.1 \\
\hline & Total & & 210 & 100.0 & 7.2 \\
\hline
\end{tabular}




\begin{tabular}{|c|c|c|c|c|c|}
\hline \multicolumn{6}{|c|}{ Occupational group } \\
\hline Code & German job title & English translation & $\mathbf{N}$ & \%OG & \%TOT \\
\hline \multicolumn{6}{|c|}{ Agriculture } \\
\hline 500 & Ackersmann & Field worker & 89 & 52.7 & 3.1 \\
\hline 510 & Fischer & Fisherman & 42 & 24.9 & 1.4 \\
\hline 520 & Gärtner & Gardener & 31 & 18.3 & 1.1 \\
\hline \multirow[t]{2}{*}{530} & Hirte, Stalldiener & Shepherd, groom & 7 & 4.1 & 0.2 \\
\hline & Total & & 169 & 100.0 & 5.8 \\
\hline \multicolumn{6}{|c|}{ Food production } \\
\hline 600 & Koch & Cook & 2 & 2.9 & 0.1 \\
\hline 610 & Bäcker & Baker & 26 & 37.1 & 0.9 \\
\hline 611 & Bäckermeister & Master baker & 2 & 2.9 & 0.1 \\
\hline 612 & Bäckergeselle & Apprentice baker & 1 & 1.4 & 0.0 \\
\hline 620 & Bierbrauer & Beer brewer & 8 & 11.4 & 0.3 \\
\hline 630 & Branntweinbrenner & Distiller & 19 & 27.1 & 0.7 \\
\hline 640 & Müller & Miller & 4 & 5.7 & 0.1 \\
\hline 650 & Lebensmittelfabrikant & Food manufacturer & 1 & 1.4 & 0.0 \\
\hline 651 & Lebensmittelfabrikmeister & Master food manufacturer & 4 & 5.7 & 0.1 \\
\hline \multirow[t]{2}{*}{652} & Lebensmittelfabrikgeselle & Apprentice food manufacturer & 3 & 4.3 & 0.1 \\
\hline & Total & & 70 & 100.0 & 2.4 \\
\hline \multicolumn{6}{|c|}{ Shipping and military } \\
\hline 700 & Seefahrer & Sailor & 7 & 1.8 & 0.2 \\
\hline 710 & Schiffer & Mariner & 149 & 38.5 & 5.1 \\
\hline 711 & Kapitän & Ship's master & 1 & 0.3 & 0.0 \\
\hline 712 & Steuermann & Steersman. ship's mate & 30 & 7.8 & 1.0 \\
\hline 720 & Matrose & Seaman & 166 & 42.9 & 5.7 \\
\hline 730 & Nachprahmer & Lighterman & 21 & 5.4 & 0.7 \\
\hline 740 & Unteroffizier, Gefreiter & Non-commissioned officer & 2 & 0.5 & 0.1 \\
\hline 741 & Hauptmann & Captain & 3 & 0.8 & 0.1 \\
\hline \multirow[t]{2}{*}{742} & Soldat & Soldier & 8 & 2.1 & 0.3 \\
\hline & Total & & 387 & 100.0 & 13.3 \\
\hline \multicolumn{6}{|c|}{ Unknown or not employed } \\
\hline 900 & Keine Angabe & Not specified & 17 & 4.1 & 0.6 \\
\hline 910 & Pensionär & Pensioner & 3 & 0.7 & 0.1 \\
\hline 920 & Nicht mehr berufstätig & No longer employed & 11 & 2.6 & 0.4 \\
\hline \multirow[t]{2}{*}{930} & Vater unbekannt & Father unknown & 386 & 92.6 & 13.3 \\
\hline & Total & & 417 & 100.0 & 14.3 \\
\hline \multicolumn{2}{|c|}{ Altogether } & & 2912 & 100.0 & 100.0 \\
\hline
\end{tabular}

Abbreviations: $N=$ Frequency, \%=share in, OG=occupational group, TOT=total number

Source: Baptismal and burial registers of St. James parish, Rostock (authors' calculation and classification)

Whereas all kinds of merchants are contained in the first group, the second category includes craftsmen such as masons, carpenters, ship's carpenters, tailors, weavers, shoemakers, blacksmiths, locksmiths, and painters; excluding craftsmen in the field of food production (see sixth category). The third group contains persons who worked as laborers, hired servants, porters and musicians, whereas administrative secretaries, bailiffs, high-level officials, jurists, physicians, clergymen, teachers, and professors form the fourth group. The fifth occupational group consists of field workers, gardeners, 
grooms, and fishermen. In the sixth category, bakers, millers, beer brewers, distillers, cooks, and tobacco and chicory manufacturers are included, whereas the seventh group contains sailors, mariners, shipmasters, steersmen, soldiers, petty officers, and captains. The residual category consists of unknown cases, pensioners, and people who are not employed any more. This group is widely congruent with the "illegitimate" category of the legitimacy variable.

Using the remarks from the registers coded as $1=$ no remarks, $2=$ deceased, $3=$ reported himself as father, $4=$ alleged father, $5=$ illegitimate, and $6=$ unknown, occupations can be recoded, e.g. in the case of illegitimate births, it is useful to code the alleged father's occupation as 930 (unknown), as the father's occupation can only have an influence on the survival of the child when he cares for his family.

\subsection{Causes of Death}

The International Classification of Diseases (ICD) could not be used for the classification of the causes of death because historical designations are not comparable to the presentday diagnoses. Other historical classifications, e.g. Kintner (1986), are not designed for the analysis of infant mortality.

Thus, we created a custom classification of the causes of death under the guidance of the medical historian Hans-Uwe Lammel $^{9}$ and on the basis of Höfler (1899). Our classification focuses on the location of the disease. It consists of the following groups: 1=respiratory disease, 2=stroke, 3=infectious disease, 4=gastro-intestinal disease, $5=$ atrophy and weakness, and $6=$ other cause, as well as the missing categories $8=$ stillbirth and $9=$ no infant death occurred. This variable can be recoded into dummy variables with the categories $0=\operatorname{did}$ not die due to cause $X$ and $1=$ died due to cause $X$, and can therefore be considered as the event variable in event history analysis or as the dependent variable in logistic regression models. This way, separate models can be analyzed according to individual causes of death.

Table 2 shows the variables sex, season of birth, legitimacy of birth, father's occupation, and cause of death along with their categories and frequencies, separated into infant deaths and survivors of the first year of life (without stillbirths).

\footnotetext{
${ }_{9}$ Professor Hans-Uwe Lammel, Doctor of Medicine, University of Rostock, Medical Faculty, Institute of Medical History
} 
Table 2: Number of deaths and survivors in the first year of life according to sex, season of birth, legitimacy of birth, father's occupation, and cause of death in St. James parish, Rostock, from 1815 to 1829

\begin{tabular}{|c|c|c|c|}
\hline Variable & Infant deaths & Survivors & Total \\
\hline \multicolumn{4}{|l|}{ Sex } \\
\hline Male & 188 & 1298 & 1486 \\
\hline Female & 163 & 1139 & 1302 \\
\hline Total & 351 & 2437 & 2788 \\
\hline \multicolumn{4}{|l|}{ Season of birth } \\
\hline Spring & 86 & 602 & 688 \\
\hline Summer & 89 & 591 & 680 \\
\hline Autumn & 89 & 599 & 688 \\
\hline Winter & 87 & 645 & 732 \\
\hline Total & 351 & 2437 & 2788 \\
\hline \multicolumn{4}{|l|}{ Legitimacy of birth } \\
\hline Legitimate & 300 & 2051 & 2351 \\
\hline Illegitimate & 51 & 386 & 437 \\
\hline Total & 351 & 2437 & 2788 \\
\hline \multicolumn{4}{|l|}{ Father's occupation } \\
\hline Trade & 26 & 180 & 206 \\
\hline Craftsmanship & 92 & 645 & 737 \\
\hline Services & 66 & 575 & 641 \\
\hline Administration and higher status occupations & 28 & 180 & 208 \\
\hline Agriculture & 30 & 134 & 164 \\
\hline Food production & 9 & 60 & 69 \\
\hline Shipping and military & 53 & 315 & 368 \\
\hline Unknown or not employed & 47 & 348 & 395 \\
\hline Total & 351 & 2437 & 2788 \\
\hline \multicolumn{4}{|l|}{ Cause of death } \\
\hline Respiratory disease & 63 & 0 & 63 \\
\hline Stroke & 18 & 0 & 18 \\
\hline Infectious disease & 29 & 0 & 29 \\
\hline Gastro-intestinal disease & 161 & 0 & 161 \\
\hline Atrophy and weakness & 72 & 0 & 72 \\
\hline Other cause & 8 & 0 & 8 \\
\hline No infant death & 0 & 2437 & 2437 \\
\hline Total & 351 & 2437 & 2788 \\
\hline
\end{tabular}

Source: Baptismal and burial registers of St. James parish, Rostock (authors' calculations and classifications)

\subsection{Birth Year Method}

The infant mortality probability (internationally better known as infant mortality rate, or $I M R$ for short) is the number of infant deaths, divided by the number of live births. However, there are several variants of calculating the IMR using different points in time as a reference. A simple variant is the calendar year method which means that the point of reference is the calendar year t. Therefore, the IMR according to the calendar year method is the number of infant deaths in the calendar year $t$, divided by the number of live births in the same calendar year t. This method, however, is not completely precise because 
infant deaths take place not only in the calendar year of birth but also in the subsequent year $\mathrm{t}+1$. This is the case when an infant born on 1 March 1815 died on 1 February 1816, for instance.

Figure 2: Birth cohorts, live births, and infant deaths (Lexis diagram)

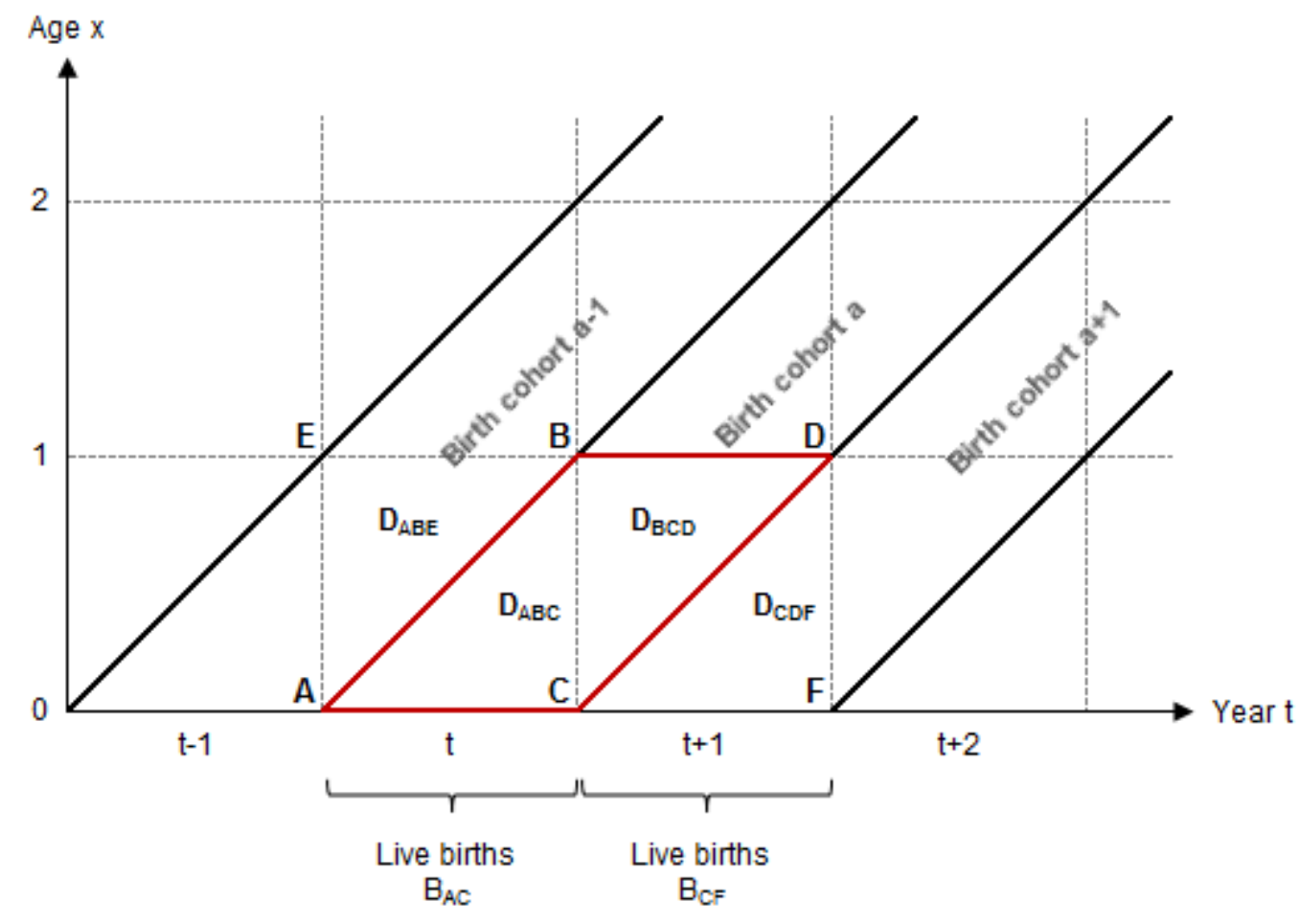

Source: Authors' design

The most precise variant is the birth year method developed by Becker $(1869,1874)$ and Zeuner (1869) ${ }^{10}$. The IMR ${ }_{1} q_{0, t}$ according to the birth year method is the share of infant deaths in a certain birth cohort or, more specifically, the number of infant deaths ${ }_{1} D_{0}$ of a birth cohort $a$, divided by the number of live births $B$ from the same birth cohort $a$ :

$$
{ }_{1} q_{0, t}=\frac{{ }_{1} D_{0, a, t}+{ }_{1} D_{0, a, t+1}}{B_{a, t}}
$$

Whereas the live births of the birth cohort $a$ are all born in the calendar year t, the infant deaths can happen in the calendar year $t$ as well as in $t+1$. Thus, the birth year method pursues a cohort approach. Based on the Lexis diagram in Figure 2, the formula reads:

$$
{ }_{1} q_{0, t}=\frac{D_{A C D B}}{B_{A C}}
$$

10 For more information on different methods for the calculation of the probability of death, see Esenwein-Rothe (1982: 241-248). 


\section{Infant and Perinatal Mortality}

The data set allows deaths to be counted according to year of birth and age at death (see Figure 3) as well as cohort based mortality measures such as infant and perinatal mortality to be calculated according to the birth year method of Becker and Zeuner (see Figures 4 and 5).

Figure 3: Frequency of deaths in the first year of life according to length of survival ${ }^{11}$ in St. James parish, Rostock, for the birth cohorts from 1815 to 1829

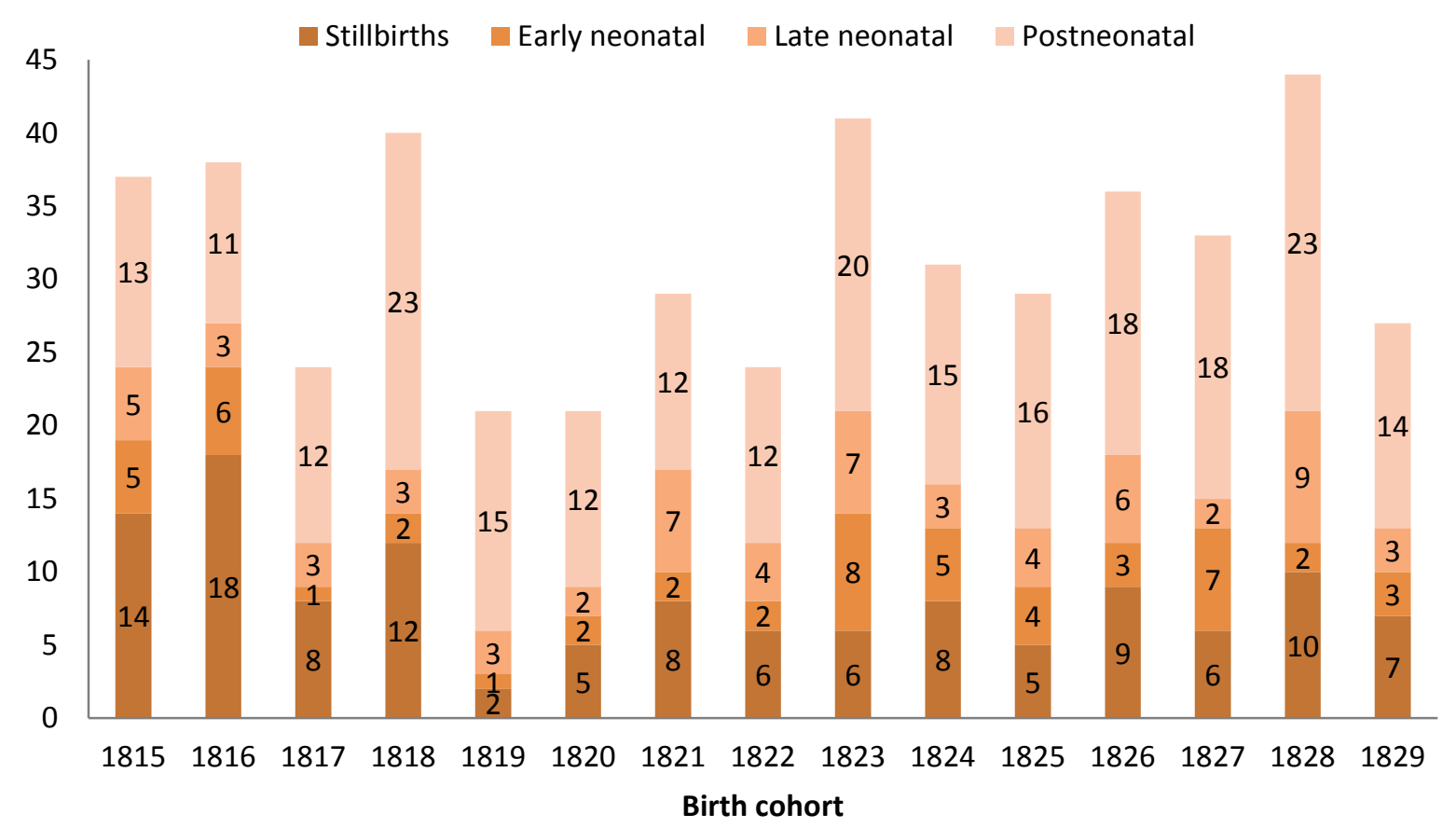

Source: Baptismal and burial registers of St. James parish, Rostock (authors' calculations)

Figure 3 shows the low and varying numbers of stillbirths and infant deaths and their inconsistent composition in the studied period according to the length of survival. The share of postneonatal deaths in the total number of deaths is the highest, except for the birth cohorts of 1815 and 1816, in which the number of stillbirths is comparatively high. In 1816, the number of perinatal deaths, i.e. the sum of stillbirths and early neonatal deaths, is greater than the number of infant deaths, which is the sum of early, late, and post-neonatal deaths.

11 Early neonatal mortality refers to deaths of live births within the first seven days of life, whereas late neonatal mortality refers to infant deaths at an age of 7 to fewer than 28 days of life. Postneonatal mortality involves all later infant deaths from day 28 up to fewer than 365 days of life (Gaber \& Wildner 2011: 23). 
Figure 4: Infant mortality rate (infant deaths per 1,000 live births) according to sex in St. James parish, Rostock, for the birth cohorts from 1815 to 1829

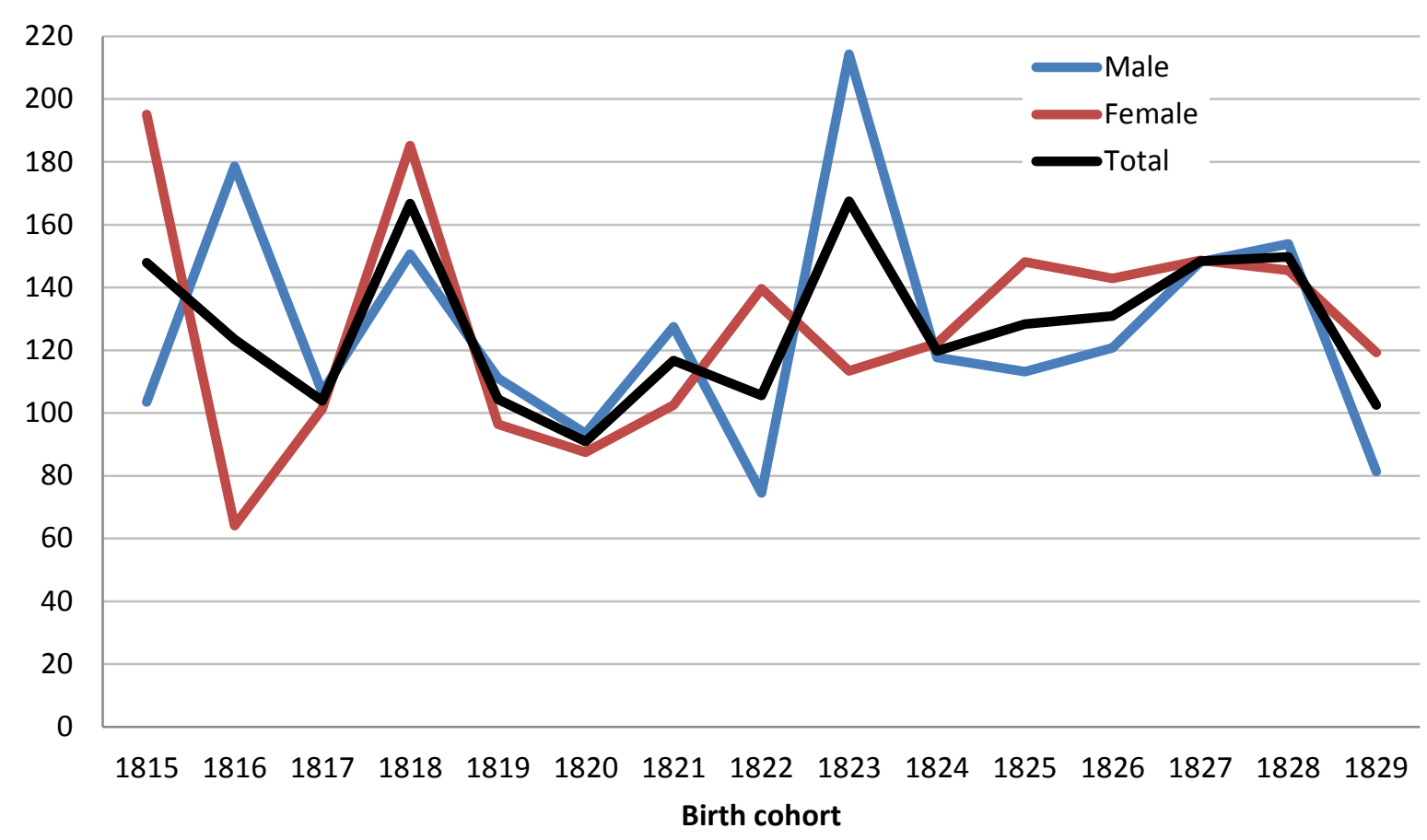

Source: Baptismal and burial registers of St. James parish, Rostock (authors' calculations)

Figure 5: Perinatal mortality rate (stillbirths and early neonatal deaths per 1,000 live births) in St. James parish, Rostock, for the birth cohorts from 1815 to 1829

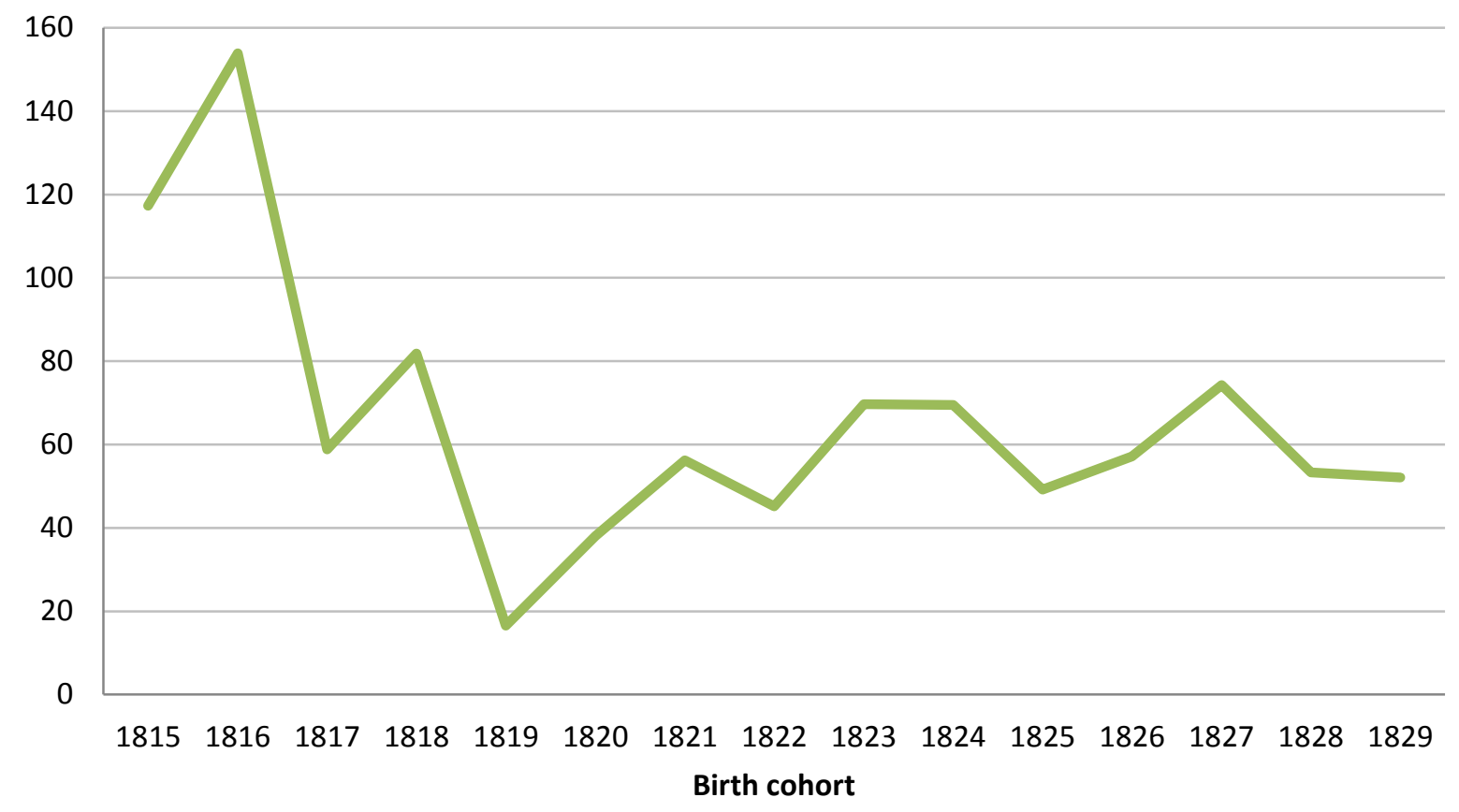

Source: Baptismal and burial registers of St. James parish, Rostock (authors' calculations)

Figure 4 shows the development of infant mortality from 1815 to 1829 in St. James parish in Rostock according to sex. In this period, no trend of infant mortality or 
differences according to sex can be observed. For the period as a whole, the infant mortality rate is 127.8 deaths in the first year of life per 1,000 live births. For boys it is 127.7 and for girls it is 127.9 .

With regard to perinatal mortality in St. James parish in Rostock (see Figure 5), a differentiation by sex is not useful because of the low numbers in perinatal deaths (3 to 24). Aside from the first two years, in which the perinatal mortality is comparatively high, no trend in perinatal mortality can be examined - also due to the short period of observation.

\section{Using the Data Set}

First calculations of infant mortality rates, based on the church records of St. James, were conducted by Schulz (2008) and Mühlichen (2011). Mühlichen et al. (2015) calculated infant mortality rates according to an adjusted calendar year method in Rostock for the entire 19th century. In addition, they measured the influence of social class on infant mortality, using models of event history analysis on the basis of the data set published as part of this technical report. Additional publications focusing on causes of death are in progress.

In combination with marriage and confirmation registries, the non-anonymized data are useful for methods of family reconstitution, genealogic studies, as well as historical and demographic analyses, e.g. concerning questions of fertility and nuptiality. By matching all these data, it is possible to calculate birth intervals, family sizes, and the age of parents at the time of childbirth. A matching of the data with the Rostock censuses of 1819,1867 , and 1900 is also possible. Furthermore, the population numbers of Rostock are available for many years of the $19^{\text {th }}$ century (see Figure 6), albeit the census methods did vary at that time (Manke 2000: 310-313).

In addition to this data set presented here, other historical data sets based on Rostock church records will soon be published online. For more information, please contact the authors of this paper. 


\section{Data description}

The data covers all births and infant deaths registered in the St. James church in Rostock over the period 1815-1829. All church books for this period are available and to our knowledge complete.

The name of the data file is EN Rostock St James 1815 1829.xls

The File includes the following variables:

Personal identification number; Year of Birth; Month of Birth; Day of Birth; Year of Christening; Month of Baptism; Day of Baptism; Year of Death; Month of Death; Day of Death; Year of Funeral; Month of Funeral; Day of Funeral; Age at Death in Days; Death (Yes/No); Perinatal Death (Yes/No); Season at Birth; Baptism; Immigration; Twins/Triplets (Yes/No); Sex; Cause of Death original; Cause of Death in our classification; Father's Occupation -our classification; Information the Father; Marital Status of the Mother at time of childbirth; Legitimacy of Birth; Information about the Mother; Occupational Group (usually of the Father).

Classifications for causes of death and occupations are given in the file.

\section{References}

Allison, Paul D. (1984): Event History Analysis. Regression for Longitudinal Event Data. Beverly Hills: Sage Publications

Becker, Karl M. L. (1869): Preussische Sterbetafeln, berechnet auf Grund der Sterblichkeit in den 6 Jahren 1859-64, auch Vergleich mit fremden Sterbetafeln. In: Zeitschrift des Königlich Sächsischen Statistischen Bureaus 9,17: 126-144

Becker, Karl M. L. (1874): Zur Berechnung von Sterbetafeln an die Bevölkerungsstatistik zu stellende Anforderungen. Berlin: Verlag des Königlichen Statistischen Bureaus

Brandenburg, Hajo; Gehrmann, Rolf; Krüger, Kersten; Künne, Andreas; Rüffer, Jörn (1991): Berufe in Altona 1803. Berufssystematik für eine präindustrielle Stadtgesellschaft anhand der Volkszählung. Kleine Schriften des Arbeitskreises für Wirtschafts- und Sozialgeschichte Schleswig-Holsteins, Band 1. Kiel: Arbeitskreis für Wirtschafts- und Sozialgeschichte SchleswigHolsteins 
Brandenburg, Hajo; Kroll, Stefan (1998): „Erwerbsstruktur“ und „Beruf”. Möglichkeiten und Grenzen einer Berufssystematik für präindustrielle Stadtgesellschaften. In: Krüger, Kersten; Kroll, Stefan (Hrsg.): Die Sozialstruktur der Städte Kiel und Altona um 1800. Demographie, Erwerbsstruktur und wirtschaftliche Leistungsfähigkeit. Studien zur Wirtschafts- und Sozialgeschichte Schleswig-Holsteins, Band 29. Neumünster: Wachholtz Verlag: 21-29

Esenwein-Rothe, Ingeborg (1982): Einführung in die Demographie. Bevölkerungsstruktur und Bevölkerungsprozess aus der Sicht der Statistik. Wiesbaden: Franz Steiner Verlag

Gaber, Elisabeth; Wildner, Manfred (2011): Sterblichkeit, Todesursachen und regionale Unterschiede. Gesundheitsberichterstattung des Bundes, Heft 52. Berlin: Robert Koch Institute

Gesenius, Heinrich J. F. (1839): Kirchliche Gesetzsammlung, enthaltend eine systematische Zusammenstellung der seit dem Jahre 1820 bis 1838 ergangenen, auf Kirche und Schulwesen bezüglichen Verordnungen und gesetzlichen Bestimmungen für Mecklenburg-Schwerin, nach Ordnung und als Fortsetzung des Siggelkowschen Handbuches, so wie der späteren Ackermannschen Sammlung. Parchim und Ludwigslust: Hinstorff'sche Hofbuchhandlung

Gesenius, Heinrich J. F. (1847): Fortgesetzte kirchliche Gesetzsammlung, enthaltend eine systematische Zusammenstellung der seit 1797-1820 und von 1839 bis Ostern 1847 ergangenen, auf Kirche und Schulwesen bezüglichen Verordnungen und gesetzlichen Bestimmungen für Mecklenburg-Schwerin, nach Ordnung und als Fortsetzung des Siggelkowschen Handbuches, so wie der späteren von 1820 bis 1839 gehenden Gesenius'schen Sammlung. Parchim und Ludwigslust: Hinstorff'sche Hofbuchhandlung

Höfler, Max (1899): Deutsches Krankheitsnamen-Buch. München: Piloty \& Loehle. Nachdruck: Hildesheim: Georg Olms (1970)

Köppe, Tobias (2010): Kirchensprengung und -abriss in der Deutschen Demokratischen Republik. http://www.kirchensprengung.de/cms/kirchensprengung_rostock.html, accessed on 25 November 2013

Kuzia, Detlef (2004): Historische Rostocker Bauwerke. Rostocker Jakobi-Kirche. Reich und doch nicht erste Adresse. http://www.mv-terra-incognita.de/beitraege/denkmale/verlorene/jakobi/jakobi1.htm, accessed on 25 November 2013 
Lorenzen-Schmidt, Klaus-Joachim (1996): Lexikon historischer Berufe in Schleswig-Holstein und Hamburg. Kleine Schriften des Arbeitskreises für Wirtschafts- und Sozialgeschichte SchleswigHolsteins, Band 2. Kiel: Arbeitskreis für Wirtschafts- und Sozialgeschichte Schleswig-Holsteins

Manke, Matthias (2000): Rostock zwischen Revolution und Biedermeier. Alltag und Sozialstruktur. Rostocker Studien zur Regionalgeschichte, Band 1. Rostock: Ingo Koch Verlag

Millies, Ernst (1895): Circular-Verordnungen des Oberkirchenraths an die mecklenburgschwerinsche Landesgeistlichkeit aus der Zeit 1849-1894. Schwerin: Herberger'sche Buchdruckerei

Millies, Ernst (1896): Die Kirchenbuchsführung in den mecklenburg-schwerinschen Kirchengemeinden. Nach amtlichen Quellen dargestellt. Schwerin: Sandmeyersche Hofbuchdruckerei

Millies, Ernst (1910): Zirkular-Verordnungen des Oberkirchenrats an die mecklenburgschwerinsche Landesgeistlichkeit aus der Zeit 1895-1909. Schwerin: Herberger'sche Buchdruckerei

Mühlichen, Michael (2011): Säuglingssterblichkeit in Rostock im 19. Jahrhundert. Eine demografische Analyse anhand von Kirchenbuchdaten. Master's thesis at the Faculty of Economic and Social Sciences of the University of Rostock

Mühlichen, Michael; Scholz, Rembrandt D. (2015): Dokumentation der Aufbereitung historischer Kirchenbuchdaten am Beispiel der Säuglingssterblichkeit in der Hansestadt Rostock. BiB Datenund Methodenberichte 2/2015. Wiesbaden: Bundesinstitut für Bevölkerungsforschung

Mühlichen, Michael; Scholz, Rembrandt D.; Doblhammer, Gabriele (2015): Social Differences in Infant Mortality in 19th Century Rostock. A Demographic Analysis Based on Church Records. In: Comparative Population Studies 2/2015 (pre-published online)

North Atlantic Population Project (2013): OCCHISCO. Occupation, HISCO Classification. https://www.nappdata.org/napp-action/variables/OCCHISCO\#codes section, accessed on 25 November 2013

Roberts, Evan; Woollard, Matthew; Ronnander, Chad; Dillon, Lisa Y.; Thorvaldsen, Gunnar (2003): Occupational Classification in the North Atlantic Population Project. In: Historical Methods 36,2: 89-96 
Scholz, Rembrandt D. (2013): Zur demographischen Entwicklung der Hansestadt Rostock im 19. Jahrhundert. In: Busch, Michael; Kroll, Stefan; Scholz, Rembrandt D. (Hrsg.): Geschichte Kartographie - Demographie. Historisch-Geographische Informationssysteme im methodischen Vergleich. Geschichte: Forschung und Wissenschaft, Band 45. Münster: LIT Verlag: 195-227

Schulz, Inga-Marie (2008): Die Säuglingssterblichkeit in Rostock im Zeitraum 1875-1910. Eine Studie auf Basis der Sterberegister der Kirchengemeinde St. Jakobi. Bachelor's thesis at the Faculty of Economic and Social Sciences of the University of Rostock

Szołtysek, Mikołaj; Gruber, Siegfried; Zuber-Goldstein, Barbara; Scholz, Rembrandt (2012): Living Arrangements and Household Formation in an Industrializing Urban Setting: Rostock 1867-1900. In: Annales de démographie historique 122,2: 233-269

Van Leeuwen, Marco H. D.; Maas, Ineke; Miles, Andrew (2002): HISCO. Historical International Standard Classification of Occupations. Leuven: Leuven University Press

Van Leeuwen, Marco H. D.; Maas, Ineke (2011): HISCLASS. A Historical International Social Class Scheme. Leuven: Leuven University Press

Zeuner, Gustav A. (1869): Abhandlungen zur mathematischen Statistik. Leipzig: Arthur Felix 


\section{Appendix}

Table 3: Variables, values and labels in the data set of St. James parish, Rostock, 1815-1829

\begin{tabular}{|c|c|c|c|}
\hline Variable & Variable label & Value range & Remark \\
\hline PersNo & Personal number & \multicolumn{2}{|l|}{ Running from 1001 to 3912} \\
\hline BYear & Year of birth & \multicolumn{2}{|l|}{1815 until 1829} \\
\hline BMonth & Month of birth & \multicolumn{2}{|l|}{1 January until 12 December } \\
\hline BDay & Day of birth & 1 until 31 & 99 unknown \\
\hline CYear & Year of christening & 1815 until 1830 & 8888 not baptized; 9999 unknown \\
\hline CMonth & Month of christening & 1 January until 12 December & 88 not baptized; 99 unknown \\
\hline CDay & Day of christening & 1 until 31 & 88 not baptized; 99 unknown \\
\hline DYear & Year of death & \multicolumn{2}{|l|}{1815 until 1830} \\
\hline DMonth & Month of death & \multicolumn{2}{|l|}{1 January until 12 December } \\
\hline DDay & Day of death & 1 until 31 & 99 unknown \\
\hline FYear & Year of funeral & 1815 until 1830 & 9999 unknown \\
\hline FMonth & Month of funeral & 1 January until 12 December & 99 unknown \\
\hline FDay & Day of funeral & 1 until 31 & 99 unknown \\
\hline \multirow[t]{3}{*}{ Days } & Age at death in days & \multicolumn{2}{|l|}{0 stillbirth } \\
\hline & & 1-357 Infant death & $\begin{array}{l}\text { Life spans of only a few minutes } \\
\text { or hours are entered as } 1 \text { day }\end{array}$ \\
\hline & & \multicolumn{2}{|l|}{99999 No infant death } \\
\hline \multirow[t]{2}{*}{ Death } & Death & 1 Yes & Stillbirths and infant deaths \\
\hline & & \multicolumn{2}{|l|}{0 No } \\
\hline \multirow{2}{*}{ Perinatal } & Perinatal death & 1 Yes & Stillbirths and early neonatal deaths \\
\hline & & \multicolumn{2}{|l|}{0 No } \\
\hline \multirow[t]{4}{*}{ Season } & Season at birth & 1 Spring & March until May \\
\hline & & 2 Summer & June until August \\
\hline & & 3 Autumn & September until November \\
\hline & & 4 Winter & December until February \\
\hline \multirow[t]{2}{*}{ Christen } & Baptism & \multicolumn{2}{|l|}{1 Yes } \\
\hline & & \multicolumn{2}{|l|}{$2 \mathrm{No}$} \\
\hline \multirow[t]{2}{*}{ Immigration } & Immigration & $1 \mathrm{Immigrated}$ & $\begin{array}{l}\text { Cases that are only registered in the } \\
\text { burial lists, not in the baptismal } \\
\text { lists (except for stillbirths) }\end{array}$ \\
\hline & & \multicolumn{2}{|l|}{2 Not immigrated } \\
\hline \multirow[t]{2}{*}{ Twin } & Twins/Triplets & \multicolumn{2}{|l|}{1 Yes } \\
\hline & & \multicolumn{2}{|l|}{$2 \mathrm{No}$} \\
\hline \multirow[t]{3}{*}{ Sex } & Sex of birth & \multicolumn{2}{|l|}{1 Male } \\
\hline & & \multicolumn{2}{|l|}{2 Female } \\
\hline & & \multicolumn{2}{|l|}{9 Not specified } \\
\hline CauseDeath & Cause of death & Original German term after ha & izing variant forms of spelling \\
\hline CauseClass & Cause of death - & 1 Respiratory disease & \\
\hline & own classification & 2 Stroke & \\
\hline & & 3 Infectious disease & \\
\hline & & 4 Gastro-intestinal disease & \\
\hline & & 5 Atrophy, weakness & \\
\hline & & 6 Other cause & \\
\hline & & 8 Stillbirth & \\
\hline & & 9 Did not die during first year & \\
\hline OccupationF & Father's occupation & Original German term after ha & izing variant forms of spelling \\
\hline OCCHISCO & Father's occupation & NAPP OCCHISCO classification & http://www.nappdata.org \\
\hline
\end{tabular}




\begin{tabular}{|c|c|c|c|}
\hline Variable & Variable label & Value range & Remark \\
\hline \multirow[t]{8}{*}{ OccClass } & Father's occupation - & 100-140 Trade & Details on sub-categories \\
\hline & own classification & 200-272 Craftsmanship & are listed in Table 4 \\
\hline & & 300-330 Services & \\
\hline & & 400-450 Administration & \\
\hline & & 500-530 Agriculture & \\
\hline & & 600-652 Food production & \\
\hline & & 700-742 Shipping, military & \\
\hline & & 900-930 Unknown, other & \\
\hline \multirow[t]{6}{*}{ RemarkF } & Remark on the father & 1 None & \\
\hline & & 2 Deceased & \\
\hline & & 3 Reported himself as father & \\
\hline & & 4 Alleged father & \\
\hline & & 5 Illegitimate & \\
\hline & & 6 Unknown & \\
\hline \multirow[t]{8}{*}{ MaritalStatus } & Marital status of the & 1 Married & \\
\hline & mother at the time & 2 Engaged & \\
\hline & of childbirth & 3 Unmarried & \\
\hline & & 4 Divorced & \\
\hline & & 5 Widowed & Father died before childbirth \\
\hline & & 6 Married but illegitimate birth & The husband is not the father \\
\hline & & 7 Widowed but illegitimate birth & \\
\hline & & $\begin{array}{l}8 \text { Divorced, widowed or married } \\
\text { but illegitimate birth }\end{array}$ & \\
\hline \multirow[t]{2}{*}{ Legitimacy } & Legitimacy of birth & 1 Legitimate & $\begin{array}{l}\text { Mother was married or engaged } \\
\text { to the child's father at the time } \\
\text { of childbirth }\end{array}$ \\
\hline & & 2 Illegitimate & $\begin{array}{l}\text { Mother was neither married nor } \\
\text { engaged to the child's father }\end{array}$ \\
\hline \multirow[t]{6}{*}{ RemarkM } & Remark on the & 1 None & \\
\hline & mother & 2 Died after childbirth & \\
\hline & & $\begin{array}{l}3 \text { Married child's father after } \\
\text { childbirth }\end{array}$ & $\begin{array}{l}\text { Incomplete since we don't have } \\
\text { this information for all births }\end{array}$ \\
\hline & & 4 Originated from another place & \\
\hline & & 5 Madame & Related to husband's social rank \\
\hline & & 6 Baroness & Wife of a baron/landowner \\
\hline Other Remark & Other remarks & - & \\
\hline
\end{tabular}

Source: Authors' classifications 
Table 4: Father's occupations in the data set of St. James parish, Rostock, 1815-1829

\begin{tabular}{|c|c|c|}
\hline Upper group & Subgroup & Description \\
\hline \multirow[t]{5}{*}{ Trade } & 100 Tradesman, other & Tradesman, wine merchant, flour merchant etc. \\
\hline & 110 Merchant & \\
\hline & 120 Grocer & \\
\hline & 130 Carter & Carter, wagoner, carriage driver \\
\hline & 140 Innkeeper & \\
\hline \multirow[t]{24}{*}{ Craftsmanship } & 200 Craftsman, other & Several other craftsmen \\
\hline & 201 Master craftsman, other & \\
\hline & 202 Apprentice craftsman, other & \\
\hline & 210 Construction worker & Mason, stone mason, builder \\
\hline & 211 Construction master & \\
\hline & 212 Construction apprentice & \\
\hline & 220 Carpenter & $\begin{array}{l}\text { Carpenter, cabinetmaker, cooper, sawyer, turner, } \\
\text { wheelwright etc. }\end{array}$ \\
\hline & 221 Master carpenter & \\
\hline & 222 Apprentice carpenter & \\
\hline & 230 Ship carpenter & Ship's carpenter \\
\hline & 231 Master ship carpenter & \\
\hline & 232 Apprentice ship carpenter & \\
\hline & 240 Textile craftsman & Tailor, weaver, hat maker, cloth maker, sail maker \\
\hline & 241 Master textile craftsman & \\
\hline & 242 Apprentice textile craftsman & \\
\hline & 250 Shoemaker & Shoemaker, pantofle maker, boot maker \\
\hline & 251 Master shoemaker & \\
\hline & 252 Apprentice shoemaker & \\
\hline & 260 Metalworker & $\begin{array}{l}\text { Blacksmith, locksmith, plumber, girdle maker, } \\
\text { brazier etc. }\end{array}$ \\
\hline & 261 Master metalworker & \\
\hline & 262 Apprentice metalworker & \\
\hline & 270 Painter & No differentiation between crafts and arts \\
\hline & 271 Master painter & \\
\hline & 272 Apprentice painter & \\
\hline \multirow[t]{4}{*}{ Services } & 300 Laborer (not otherwise specified) & \\
\hline & 310 Hired servant, day laborer & \\
\hline & 320 Porter & \\
\hline & 330 Musician & \\
\hline \multirow[t]{8}{*}{ Administration } & 400 Clerk, administrative secretary & Secretary, copyist, academic book printer \\
\hline & 401 High-level official & Calculator, supervisor, counselor etc. \\
\hline & 402 Low-level official & Mayoral servant, beadle, grave-digger, bailiff \\
\hline & 410 Jurist & $\begin{array}{l}\text { Advocate, notary, syndic, Doctor of Laws, } \\
\text { protonotary, chancery director, chancery clerk }\end{array}$ \\
\hline & 420 Teacher, professor & \\
\hline & 430 Clergyman & Deacon, pastor, cantor \\
\hline & 440 Physician & \\
\hline & 450 Nobleman, landowner & \\
\hline \multirow[t]{4}{*}{ Agriculture } & 500 Field worker & \\
\hline & 510 Fisherman & \\
\hline & 520 Gardener & \\
\hline & 530 Shepherd, groom & \\
\hline
\end{tabular}




\begin{tabular}{lll}
\hline Upper group & Subgroup & Description \\
\hline Food production & 600 Cook & \\
& 610 Baker & \\
& 611 Master baker & \\
& 612 Apprentice baker & \\
& 620 Beer brewer & \\
& 630 Distiller & Chicory manufacturer \\
& 640 Miller & Master tobacco manufacturer \\
& 650 Food manufacturer & \\
& 651 Master food manufacturer & \\
& 652 Apprentice food manufacturer & Apprentice tobacco manufacturer \\
\hline & 700 Sailor & \\
\hline Shipping / military & 710 Mariner & \\
& 711 Ship's master & \\
& 712 Steersman, ship's mate & \\
& 720 Seaman & \\
& 730 Lighterman & \\
& 740 Non-commissioned officer & \\
& 741 Captain & \\
& 742 Soldier & \\
& 900 Not specified & \\
& 910 Pensioner & \\
& 920 No longer employed & \\
& 930 Father unknown & \\
\hline
\end{tabular}

Source: Authors' classifications

Figure 6: Population development in Rostock from 1792 to 2013

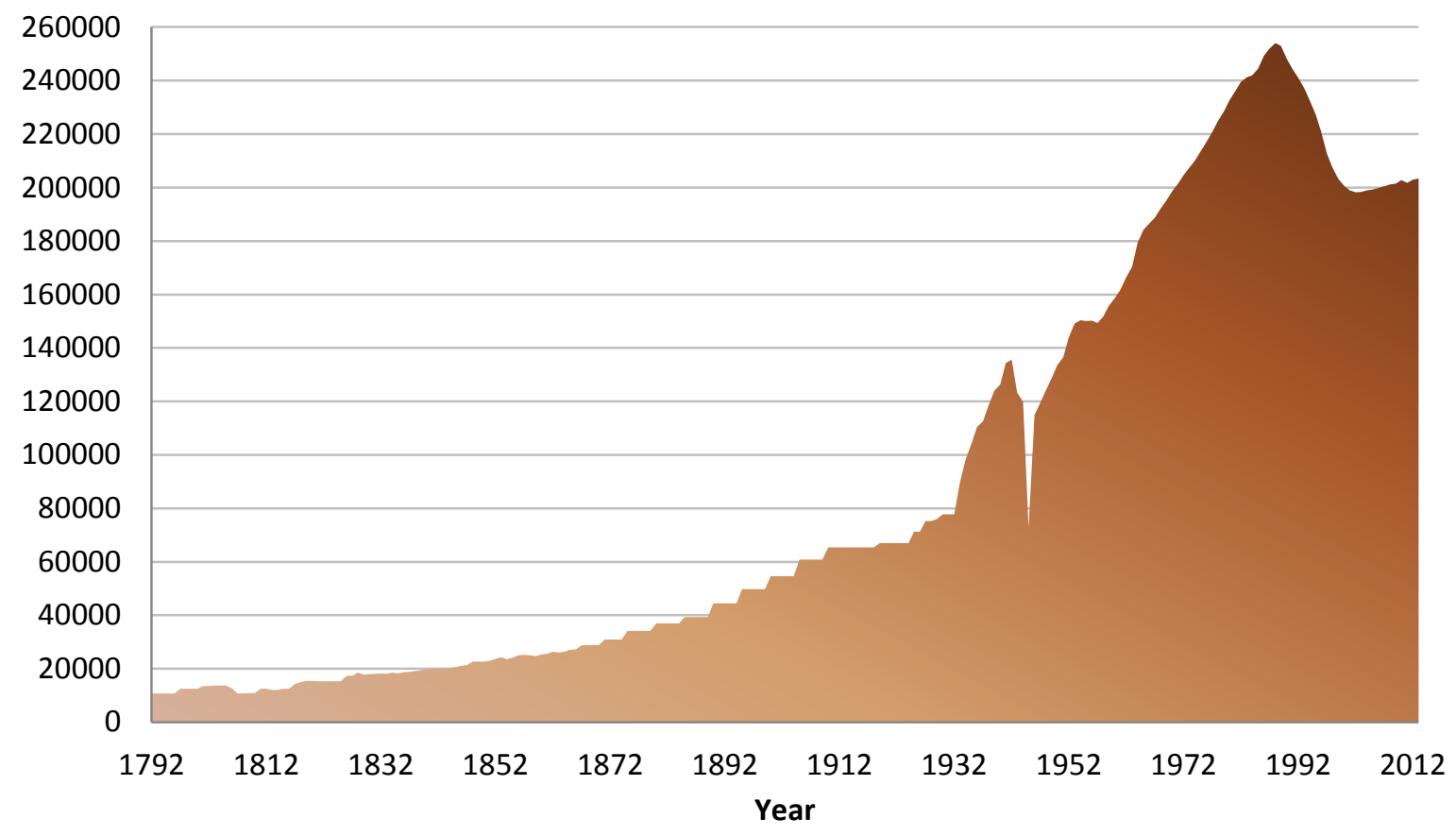

Source: Kommunale Statistikstelle der Hansestadt Rostock; Staatskalender von Mecklenburg-Schwerin 
Figure 7: St. James's Church (Jakobikirche) in Rostock, around 1920

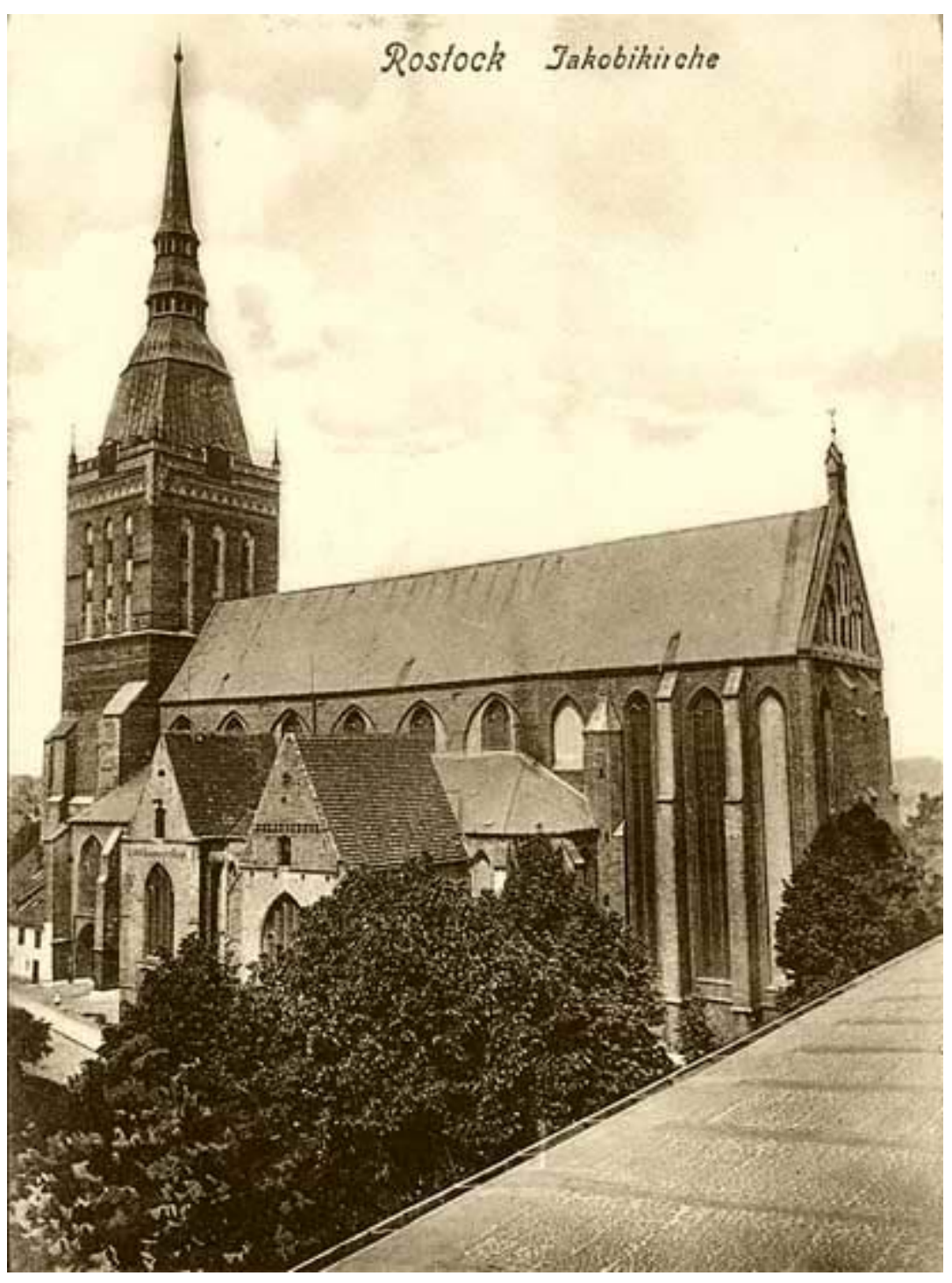

Source: Archiv Berthold Brinkmann (MV-Terra-Incognita.de) 